\title{
HALBWACHS NO HOLODECK: jogos eletrônicos e memória coletiva
}

\section{HALBWACHS NO HOLODECK: electronic games and collective memory}

\author{
Helyom VIANNA-TELLES ${ }^{1}$
}

Resumo: Este trabalho discute alguns resultados de uma pesquisa cujo objetivo era investigar se a experiência lúdica dos jogos eletrônicos pode atuar como um suporte para memória coletiva e para produção e no compartilhamento de representações, de imagens e de um imaginário sobre o passado. Trata-se também de uma discussão sobre memória coletiva, multimodalidade e jogos eletrônicos, centrada na análise do jogo Assassin's Creed II. Os dados foram coletados com o recurso à um microetnografia do game play. Ao longo do texto, demonstro como estudos sobre jogos como Call of Duty, Medal of Honor sugerem que alguns videogames podem assumir inúmeras funções mnemônicas como simulação, celebração, narrativa, produção de monumentos, vivência do luto, rememoração e patrimonialização. Os recursos multimodais presentes em jogos eletrônicos como Assassin's Creed II podem ampliar as possibilidades de compartilhamento da memória coletiva.

Palavras-chave: Memória Coletiva; Jogos Digitais; Multimodalidade; Assassin's Creed II.

Abstract: This paper discusses some results of a study whose objective was to investigate whether playful experience of video games can act as a support for collective memory and for the production and sharing of representations, images and an imaginary about the past. It is also a discussion of collective memory, multimodality and electronic games, focused on the analysis of the game Assassin's Creed II. Data were collected with the use of a micro ethnography of game play. Throughout the text, demonstrate how studies on games like Call of Duty, Medal of Honor suggest that some games can take several memory functions like as simulation, celebration, storytelling, production of monuments, experience grief, remembrance and patrimonialization. Multimodal resources present in video games such as Assassin's Creed II can expand the sharing possibilities of collective memory.

Keywords: Collective Memory; Digital Games; Multimodality; Assassin's Creed II.

Pós-Doutorado em Educação e Contemporaneidade pela Uneb (2015) e Doutor em Ciências Sociais pela Universidade Federal da Bahia (2009). Coordenador do Núcleo de Antropologia Digital, História Oral e Visual-NAHV e Pesquisador vinculado ao Grupo Comunidades Virtuais (PPGEduCUNEB). Pesquisador filiado às seguintes organizações: American Anthropological Association, American Historical Association, Asociación Antropólogos Iberoamericanos En Red, Associação Nacional de Professores Universitários de História (ANPUH) e Sociedade Brasileira de Teoria e História da Historiografia (SBTHH). Professor da Universidade Estácio de Sá e do IHAC - Instituto de Humanidades, Artes Ciências Professor Milton Santos da Universidade Federal da Bahia. E-mail: helyom@gmail.com; helyom@ufba.br. 


\section{míDiA \\ ec DiAno}

\section{Introdução}

As reflexões apresentadas neste artigo foram em parte originadas por uma pesquisa de pós-doutorado desenvolvido junto ao Grupo de Pesquisa Comunidades Virtuais, vinculado ao Programa de Pós-Graduação em Educação e Contemporaneidade da Universidade do Estado da Bahia (UNEB), sob a supervisão da Professora Lynn Alves. O projeto contou com financiamento da CAPES/FAPESB e, de modo geral, teve por objetivo discutir a relação entre História, Memória Social e Jogos Eletrônicos. Contudo, no desenrolar da pesquisa, percebi que a meta era, por demais, ambiciosa. Se a discussão sobre jogos eletrônicos e História produziu resultados significativos naquele período, a pesquisa sobre memória pôde avançar apenas posteriormente durante um novo ciclo de pesquisa, este desenvolvido junto ao Programa de Pós-Graduação em Estudos Interdisciplinares sobre a Universidade da Universidade Federal da Bahia, onde obtive resultados na discussão sobre memória coletiva, multimodalidade e jogos eletrônicos, tema do qual trato neste artigo. Ambas as pesquisas tomaram como referência a análise do videogame Assassin's Creed II. Em função do caráter interdisciplinar do periódico, creio que a contextualização da pesquisa feita acima é importante, pois, para campos como Educação, Teoria da História e Ensino de História, as questões trazidas pela investigação das relações entre jogos digitais e o conhecimento do passado são vistas com grande interesse. Nessas áreas, o processo de abertura para a reflexão sobre as tecnologias digitais e a cultura vem ocorrendo de forma mais lenta, se comparado ao que se dá no campo das Ciências da Comunicação. Desse modo, é possível que alguns pesquisadores desse campo não encontrem uma novidade expressiva ou frescor significativo em algumas das questões aqui levantadas.

É preciso sublinhar que a pesquisa conduzida colocou problemas que vão além da mera constatação de que, no jogo aludido, existem representações sobre o passado e, mais precisamente, representações sobre o Renascimento italiano, uma vez que a investigação procurou entender precisamente isto: como o jogo dialoga com a História e a Memória do período referido. Nesse sentido, apesar da avaliação entusiasta da dimensão lúdica do jogo feita por jornalistas como Kaylan (2013), os historiógrafos, estudiosos da Educação e professores de História, ao se debruçarem sobre os jogos 


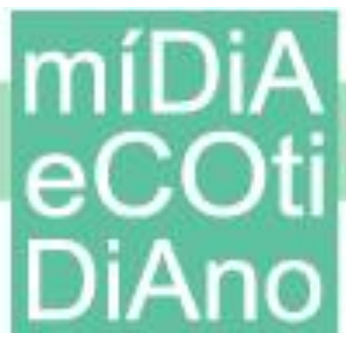

eletrônicos, precisam deixar para trás a dimensão do entretenimento e trazer para o primeiro plano o problema da precisão histórica ou científica de uma narrativa ou simulação digital. Essa preocupação é, sobretudo, muito viva para o último grupo, quando indaga sobre as possibilidades de uso didático dos jogos.

Outra questão, igualmente importante, que tratei em um trabalho anterior (VIANA-TELLES; ALVES, 2016a) diz respeito à rejeição de um apriorismo ingênuo na avaliação de jogos eletrônicos, que afirma que todas as representações do passado neles existentes são históricas. Ao contrário, sustento que o investigador precisa constituir isto como um problema, a saber, o de identificar qual a origem e natureza dessas representações, sob pena de perder de vista, precisamente, a complexidade e a riqueza das mesmas. É preciso notar que os videogames dialogam com inúmeras influências, a exemplo da literatura, do cinema e da memória coletiva. Em função disso, a análise que conduzi procurou compreender como o nível ficcional, o imaginário e o histórico se articulam na experiência do jogo, oferecendo, desse modo, uma abordagem diferenciada que tenta aproximar o lúdico e o científico. Essa perspectiva vai além da mera assunção da aproximação ou permeabilidade de um jogo às narrativas históricas. Ela traz uma preocupação epistemológica, a saber, a necessidade de identificar qual perspectiva de História é retratada em um jogo eletrônico e como isso se dá.

Meu interesse pelo campo das representações e da memória como construção social não é novo. Remonta à pesquisa que resultou em minha tese de doutorado (VIANA-TELLES, 2009). Já naquele período, havia notado a necessidade de compreender como os recentes desenvolvimentos e convergências engendrados a partir do desenvolvimento das tecnologias da comunicação e informação atuam sobre a história e a memória coletiva. Também vejo nesse artigo uma resposta às provocações do Professor Leonardo Nascimento que, em nossos debates sobre o campo da sociologia digital, sugeriu a impossibilidade de abordar as implicações das interações mediadas por tecnologias digitais para construção social da memória a partir do referencial teórico de Halbwachs (1994, 2003). Sustento a posição contrária: penso que esse fenômeno confere ainda mais importância para o quadro teórico desenvolvido por esse autor. 


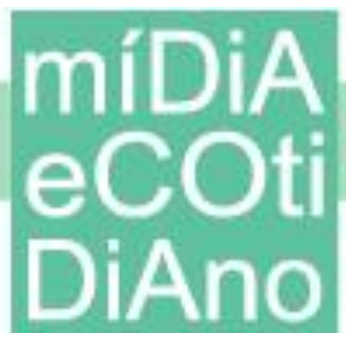

Acredito, inclusive, que a obra de Halbwachs ainda não recebeu a atenção devida por parte dos cientistas sociais.

Aqui, cabe outro esclarecimento importante para situar o leitor diante das discussões que virão a seguir. Para Historiografia e as Ciências Sociais, História e Memória não são sinônimos. A lógica da memória diferencia-se da lógica da História, na medida em que a primeira não deve ser, precisamente, entendida como uma representação de fatos que realmente ocorreram. A memória responde às demandas de um grupo social que escolhe o que deve ser lembrado e esquecido (VIANNA-TELLES, 2009). Ao tratar desse tópico, Dosse (2003) afirma que a conceptualização da memória coletiva proposta por Halbwachs tem como ponto de inflexão o seu enraizamento a comunidades e grupos sociais. O conceito foi construído opondo, de modo antitético, Memória e História, ou seja é possível falar em múltiplas memórias, mas há apenas uma História. A Memória coletiva se relaciona ao concreto, ao plural por fazer referência ao que foi vivido por inúmeras comunidades; ao imaginário, ao mito, a um tempo existencial fértil de significados, à subjetividade. Já a História, enquanto disciplina científica, é marcada por acontecimentos, cronologias, pela crítica, pela conceitualização, pela laicização e pela objetividade. Em Halbwachs, a História viria apenas com o fim da Memória. Contudo, esse é um debate que está longe de ser encerrado. Mais recentemente, tem crescido a tendência para pensar a interpenetração entre esses campos, em lugar de pensá-los como posições estanques. Por exemplo, Ricoeur (2007) aponta que a Memória pode reapropriar-se de um passado instruído ou ferido pela História e que abordagens como a História Cultural e História das mentalidades tentaram fazer da Memória um objeto da História. Portanto, ao indagar sobre a relação entre História e Memória Coletiva no jogo Assassin’s Creed II, trato de diferentes ordens de representações.

De fato, o trabalho de Mukerjee (2013) já havia identificado a pertinência do tema da memória para a análise desse videogame. No entanto, ele não o fez na perspectiva da memória coletiva, abordagem que entendo ser capaz, não apenas de ampliar a compreensão da experiência do jogo, mas de revelar a importância da pesquisa sobre jogos eletrônicos para a compreensão de processos culturais contemporâneos como a 


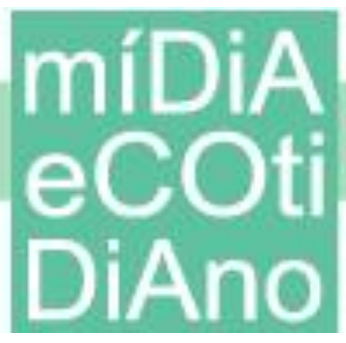

produção e o compartilhamento de memórias. Em função dos objetivos propostos neste artigo, não me aprofundarei na descrição dos elementos da simulação digital. Há uma análise bastante detalhada sobre esse aspecto no trabalho de Dow (2013), que possui como fraqueza, exatamente a elisão da discussão sobre as camadas narrativas do jogo. Por fim, como o título do artigo indica, busco aqui estabelecer um diálogo entre a abordagem narratológica de Murray (2003) para os jogos eletrônicos, que os pensa enquanto narrativas interativas e o campo de estudo sobre a memória coletiva. Desse modo, é precisamente sobre os elementos narrativos do jogo que me deterei.

$\mathrm{O}$ artigo está estruturado da seguinte forma: $\mathrm{Na}$ primeira seção, apresento o conceito de memória coletiva e procuro demonstrar sua imbricação com a dimensão da ficção e do imaginário. Na seção seguinte, aponto algumas leituras sobre as implicações resultantes da confluência entre mídia, tecnologia digital e memória na perspectiva do campo interdisciplinar conhecido como memory studies. Na seção posterior, trato da relação entre memória coletiva e jogos eletrônicos em alguns trabalhos de pesquisadores que se debruçaram sobre jogos como Call of Duty e Medal of Honor. Por fim, apresento uma análise mais aprofundada sobre a articulação entre ficção histórica e memória no jogo Assassin's Creed II.

\section{Memória coletiva, mídia e memory studies}

As investigações sobre os mecanismos coletivos da memória tiveram início no final do século XIX, com os trabalhos de Bartlett (1977) e Halbwachs (1990). Até então, a memória era um problema abordado pela Filosofia ou pela Psicologia, e compreendida em termos puramente biológicos ou individuais. Halbwachs, na esteira do programa de pesquisa aberto pela escola sociológica francesa liderada por Émile Durkheim, inovou ao abordar memória como uma construção coletiva. Isso significa tratar a recordação como uma construção social, ou seja, só é possível lembrar com base nos quadros sociais oferecidos por um determinado grupo. Pensa a memória essencialmente enquanto uma experiência coletiva. Para ele, não é possível apreendê-la individualmente. A sua origem é social. Ela faz parte de um conjunto de sentimentos e pensamentos que estão presentes no indivíduo, mas não se originaram nele, sendo-lhe 


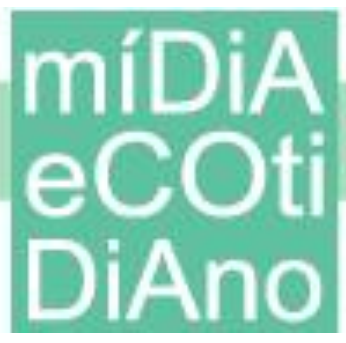

pré-existentes. Ao colocar a dimensão do social antes do nível do individual para a investigação dos fenômenos mnemônicos, Halbwachs filiou-se ao programa proposto de investigação sobre as representações coletivas proposto por Durkheim. Oliveira (1993) sublinha que esse programa inaugurou uma antropologia do conhecimento, cujo objetivo era compreender não apenas como as sociedades se pensam, mas também, como são construídas as representações coletivas que possibilitam a vida coletiva e dão significado ao grupo.

Retomando as categorias aristotélicas e sob a influência neokantiana, a Escola Francesa de Sociologia desenvolveu estudos sobre cada uma dessas categorias com o objetivo de demonstrar o caráter social da sua construção e a sua importância na compreensão dos atos comunicativos humanos. Se a existência de categorias do entendimento é um fenômeno universal a todos os grupamentos humanos, as representações coletivas, por sua vez, são variáveis. Independentemente do seu estágio de desenvolvimento, todos os grupamentos humanos apresentarão as mesmas categorias, diferindo, no entanto, na forma como se apresentam em cada sociedade (PINHEIRO FILHO, 2004, p. 153).

Em 1925, Halbwachs publicou Les Cadres Sociaux de la Memorie. Essa foi a primeira obra a propor a análise da memória a partir de uma perspectiva sociológica, dentro de um quadro conceitual que ele entendia como "morfologia social" (SANTOS, 2000). Construiu a memória como um fato social, do mesmo modo como Durkheim fez com o suicídio, ou seja, retirou-a do reino da subjetividade e a trouxe para o campo dos estudos comportamentais. Naquela obra, já estão presentes os princípios para a teoria da memória, que desenvolveu posteriormente. Seus trabalhos fazem parte de um projeto mais amplo, que objetivava o desenvolvimento científico de uma teoria social compreensiva. Nesse sentido, aproxima-se tanto de Durkheim quanto de Weber, uma vez que ambos desejavam compreender os mecanismos da produção de sentido na vida social.

Com o conceito de memória coletiva, Halbwachs (1990) entende que toda memória é estruturada em termos das identidades dos grupos a que pertencemos. É através da pertinência e das experiências grupais que as lembranças são estruturadas. 
Desse modo, as nossas memórias são entendidas como sendo uma parcela das memórias de uma dada comunidade. Pensamos e lembramos como membros de um determinado grupo. Ao fazê-lo, adotamos o seu ponto de vista e utilizamos todas as noções que lhe são comuns. Necessitamos de uma "comunidade afetiva" para recordar. Halbwachs explica a capacidade de recordar a partir da nossa inserção grupal e o esquecimento pelo nosso afastamento desse grupo. Para ele, quando esquecemos um período de nossa vida é porque nos afastamos daqueles com os quais esse período foi vivenciado. Da mesma forma que as nossas categorias de pensamento são sociais, as nossas representações sobre o passado também são de ordem coletiva. Não apenas pensamos, mas também lembramos como membros de um grupo social. Ao fazê-lo, adotamos o seu ponto de vista e as noções que the são comuns. Se determinado processo ou fato ocorrido no passado nos escapa, isso se dá pela ausência de relevância que este possuiu na vida coletiva de um determinado grupo.

A ideia de uma solidariedade mnemônica atravessa todo o texto da Memória Coletiva. Apoiamo-nos uns nos outros para lembrar. Como a produção de lembranças é decorrente da socialização, a primeira infância não pode ser recordada. Halbwachs é cético em relação a esse ponto e entende que, mesmo quando afirmamos que nos lembramos de algo sobre esse período, recordamos, em realidade, as narrativas que nossos familiares fizeram sobre ele. Nossa imaginação associa-se a essas narrativas conferindo-lhes vida, ilustrando-as com um conjunto de imagens. A repetição constante dessas narrativas - juntamente com produção de imagens sobre elas - leva à associação das mesmas com o nosso passado.

A memória seria composta de um conjunto de imagens e narrativas compartilhadas. Não teríamos o passado, mas apenas as representações sobre ele. De um ponto de vista funcional, o indivíduo lida, a todo o momento, com duas espécies de lembranças: as de caráter pessoal, que lhe são específicas por tratarem de fatos relativos à sua individualidade; e as impessoais, por dizerem respeito a todo um grupo do qual faz parte e também participa do trabalho de manutenção dessas lembranças. Ao mesmo tempo, apoia-se na memória coletiva para esclarecer fatos e eventos da sua própria memória individual. Do mesmo modo, o indivíduo necessita do auxílio dos outros para 
"lembrar-se" de eventos dos quais não tomou parte e de cuja existência tomou conhecimento através de outras fontes. Ao longo do texto da Memória Coletiva, Halbwachs refere-se a duas dessas fontes, em especial as narrativas históricas e as narrativas literárias. Elas interagem com a imaginação criando quadros vivos que alimentam a memória dando significado ao mundo e aos lugares:

Eu me lembro de Reims porque ali vivi todo um ano. Lembro-me também que Joana D'Arc foi a Reims e que ali sagrou Carlos VII, porque ouvi dizer ou porque li. Joana D'Arc foi representada tantas vezes no teatro, no cinema etc., que não tenho deveras nenhuma dificuldade de imaginar Joana D'Arc em Reims. Ao mesmo tempo, sei bem que não me foi possível ser testemunha do próprio acontecimento; atenho-me aqui às palavras que ouvi ou li, sinais reproduzidos através do tempo, que são tudo o que me chega desse passado. (HALBWACHS, 1990, p. 59)

Um dos primeiros exemplos da interação entre memória e imaginário através das narrativas literárias é oferecido logo nas primeiras páginas da Memória Coletiva. Halbwachs tenta mostrar como a presença coletiva estrutura a produção das lembranças individuais recuperando a experiência da sua primeira visita à Londres. As suas lembranças de Londres não eram apenas as recordações dele sobre a cidade, mas recordações do que lhe fora dito sobre a cidade e, sobretudo, do que já havia lido sobre ela:

\begin{abstract}
A primeira vez que fui a Londres, diante de Saint-Paul ou Mansion-House, sobre o Strand, nos arredores de Courts of Law, muitas impressões lembravam-me os romances de Dickens lidos em minha infância: eu passeava então com Dickens. Em todos esses momentos, em todas essas circunstâncias, não posso dizer que estava só, que refletia sozinho, já que eu compunha com esse arquiteto, além deste, com aqueles, dos quais ele era intérprete junto a mim, ou aquele pintor (e seu grupo), com o geômetra que havia desenhado esse plano, ou com um romancista. Outros homens tiveram essas lembranças em comum comigo. (HALBWACHS, 1990, p. 31)
\end{abstract}

Se as narrativas literárias e a ficção ofereciam material e suporte para a memória, o que acontece quando a literatura passa a ser construída e consumida com base em mídias ou multimeios interativos? Quais as consequências da digitalização para a memória coletiva? Em Hamlet no Holodeck, Murray (2003) sustenta que o desenvolvimento de novas formas narrativas através da mediação do computador e da simulação digital levou o fenômeno da narratividade humana para um outro patamar criativo e produziu novas sensibilidades. A autora argumenta que essa narrativa, uma 


\section{míDiA

vez ambientada nos espaços digitais, adquire propriedades singulares como a interação e a execução de tarefas em ambientes ficcionais navegáveis caracterizados por uma elevada capacidade de armazenamento da informação. Trata-se de um meio procedimental que requalifica o expectador como interator, uma vez que exige a sua interação com um cenário digital para que a narrativa se desenrole. São três os conceitos propostos para apreender a experiência estética proporcionada pelos games: imersão, agência e transformação. O computador e os ambientes digitais, pensados enquanto meios de expressão e comunicação, são definidos sendo procedimentais, participativos, espaciais e enciclopédicos. A procedimentalidade diz respeito à capacidade dos computadores de executarem instruções e produzirem ambientes gerados a partir dessas regras.

A participação está relacionada à capacidade do interator introduzir, ele próprio, comportamentos nesses ambientes e também ao prazer de visitar e atuar nesses ambientes como um outro lugar. A espacialidade diz respeito à propriedade única dessas mídias digitais. Enquanto livros e filmes apresentam o espaço através de descrições verbais ou imagens, os ambientes digitais o fazem através da criação de espaços navegáveis.

O enciclopedismo é resultante da capacidade crescente dos computadores de processarem, acumularem e trocarem entre si imensas quantidades de dados digitalizados, de modo a produzirem densas narrativas e representações amplas e detalhadas do mundo. A interatividade surge como uma experiência que resulta da articulação entre procedimentalidade e participação; enciclopedismo e espacialidade resultam na experiência da imersão. A experiência estética produzida por esse tipo de mediação tem características particulares e seria capa de originar efeitos emocionais de densidade substancial, a que Murray chama de transformação. As sensações de imergir, participar em outro lugar, atuar e provocar mudanças no universo ficcional do qual se participa levariam o interator a experimentar constantes transformações subjetivas:

As histórias certas podem abrir nossos corações e mudar o que somos. As narrativas digitais acrescentam um novo e poderoso elemento a esse potencial, oferecendo-nos a oportunidade de encenar histórias ao invés de simplesmente testemunhá-las. Acontecimentos encenados tem um poder transformador que excede tanto o dos fatos narrados quanto dramatizados, 
pois nós os assimilamos como experiências pessoais. O impacto emocional da transformação dentro de um ambiente imersivo é tão forte que instalações de realidade virtual foram consideradas eficazes para psicoterapia. (MURRAY, 2003, p. 166)

Acredito que a trilogia Matrix, guardadas as devidas proporções, possa ter, em seu universo ficcional, oferecido uma interessante imagem para esse processo. Talvez possa chama-lo de "Efeito Neo". Em determinado momento da narrativa, Neo, o protagonista, que se destaca por possuir a capacidade de manipular o digital, adquire o poder de controlar as máquinas no mundo real, ao mesmo tempo em que seu antagonista, o Agente Smith, torna-se capaz de possuir seres humanos e operar através deles. Está presente aí a ideia de que a intensa participação e a imersão em um mundo digital podem ocasionar mudanças efetivas na percepção e atuação sobre as interações sociais que vierem a ocorrer fora dele, em outros contextos interativos. Como é sabido, o uso dos simuladores digitais para os mais diversos treinamentos parte da premissa de que é possível uma transferência de aprendizagem do que foi vivenciado "lá" para o que será realizado "aqui" (SHAFFER, 2007). Dito de outra maneira, há a expectativa de que a construção de uma memória com base em experiências digitais venha a influenciar no reconhecimento e no desempenho de atividades que ultrapassam a esfera do digital. Segundo Dow (2013), o digital pode "vazar", disseminar-se no real de diferentes modos e intensidades diversas. Ele interessou-se pela análise das relações entre História e simulação digital foi estimulado pelos depoimentos de vários estudantes de graduação em História, que lhe confidenciaram que, após interagirem com Assassin's Creed 2 e visitarem Florença, experimentaram a vívida sensação de reconhecimento da cidade a partir das lembranças do jogo. Ao utilizar a expressão "vazamento" do digital, Dow quis traduzir o processo através do qual, as representações adquiridas dentro do jogo, foram projetadas para fora dele como um esquema de apreensão e significação da realidade social. De modo mais preciso, nos termos de Halbwachs, isso significa dizer que o jogo ofereceu um enquadramento social para a memória dos estudantes.

Murray (2003) chegou a postular a existência de um processo evolutivo da narratividade humana, que teria tido início com o compartilhamento das narrativas dos mitos até a atual complexidade dos ambientes digitais e tecnologias da comunicação. Também reconheceu a importância do fenômeno narrativo para os processos de 
cognição e construção de identidade. Parece-me, então, que ela foi levada diretamente ao encontro do problema da digitalização e as reconfigurações da memória coletiva mas, infelizmente, não o reconheceu. Ao restringir sua análise ao plano das narrativas ficcionais, a autora apenas arranhou timidamente a superfície de um iceberg. Seria necessário aprofundar-se e ter levado o inquérito bem mais adiante de modo a investigar também ou campos, a saber, o das narrativas que aspiram a adesão à verdade e o das narrativas que dialogam com diferentes perspectivas de verdade. Numa palavra, era preciso ter indagado sobre a História e sobre a Memória, uma vez que os ambientes digitais permitem a reflexão sobre os significados mais profundos inerentes aos conteúdos narrativos:

\begin{abstract}
Um dos resultados de tal exploração seria uma apreciação mais imediata de processos. Enquanto o romance permite-nos explorar os personagens e o teatro possibilita que exploremos a ação, a narrativa de simulação pode nos permitir a exploração do processo. Porque o computador é um meio procedimental ele não se limita a descrever ou observar padrões de comportamento, como os textos impressos e os filmes o fazem; ele incorpora e executa esses padrões. E como meio participativo que é, ele permite que colaboremos na performance. Usando o computador podemos encenar, modificar e compreender processos, como nunca havia sido possível. Também podemos pela primeira vez apreciá-los esteticamente, saborear complexos padrões de processos da mesma fora que saboreamos padrões e formas. (MURRAY, 2003, p. 175)
\end{abstract}

Uma vez que o trabalho da memória coletiva é também alimentado e vitalizado por narrativas literárias e imagens ficcionais, o cenário descrito por Murray (2003) abre espaço para que a indagação sobre as relações entre jogos eletrônicos e memória coletiva seja vista com interesse por pesquisadores de ambos os fenômenos. Para o pesquisador dos jogos eletrônicos, o entendimento da articulação entre simulação e narrativa, presente nos trabalhos da memória, pode vir a constituir-se como referencial útil para a compreensão das características internas dos jogos eletrônicos. De outro lado, as pesquisas sobre memória coletiva podem ampliar a compreensão sobre a dinâmica entre novos suportes sociotécnicos, narrativas e práticas mnemônicas reconfiguradas ou ampliadas com o recurso à simulação digital. É preciso lembrar que a associação entre memória e simulação não é nova. São Tomás de Aquino inclui, entre as quatro regras que propõe para a arte da mnemônica, a construção ou invenção de simulacros (AQUINO, 2004). 


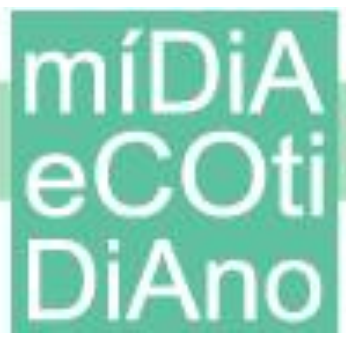

Também cabe notar que a articulação entre desenvolvimento tecnológico e memória remontam ao aparecimento da escrita. Com esta, ocorreu a aceleração de um processo de artificialização e de exteriorização da memória, que teve início com a hominização, transformando a aparência da memória e criando a noção da lembrança como um registro (LEVY, 1998). Todas as sociedades humanas enfrentam o problema da inscrição e da conservação dos conhecimentos que, aumentando aceleradamente, produziu formas cada vez mais complexas de suportes mnemônicos, culminando com o desenvolvimento da memória eletrônica (LEROI-GOURHAN, 1987). É nesse sentido que, tanto a memória individual como a social são construídas com base em suportes tecnológicos, que Le Goff (2003) propõe refletir sobre uma história das práticas mnemônicas.

Contudo, pesquisadores têm apontado que a percepção do passado, e das maneiras sobre como o passado afeta o presente, depende cada vez mais do recurso a símbolos midiáticos. Estaria ocorrendo, inclusive, um intenso processo de revisão do passado coletivo (THOMPSON, 1988), que reposiciona a função da mídia como um órgão de historicização (CRUZ, 2002). As imagens digitais possibilitam a criação de modelos que podem ser manipulados, alterados, desconstruídos, experimentados e reconstruídos e levam o corpo a experimentar o inteligível de modo tangível. Trata-se de um novo contexto visual que impacta sobre os saberes, o ensino, a escrita e a memória (QUEAU, 1993, p. 92).

Não é à toa que as relações entre mídia e memória ocupam lugar relevante nos debates do campo interdisciplinar conhecido como memory studies (ROEDIGER; WERTSCH, 2008). Tem crescido no campo o interesse pela compreensão do papel da mídia na construção de políticas públicas de recordação, produzindo pesquisas que trazem as seguintes perguntas: Como esses modos de lembrar podem operar como representações coletivas do passado? Como atuam fornecendo referenciais culturais para a construção de identidades coletivas? Quais leituras do passado são privilegiadas em detrimento de outras (KEIGHTLEY; PICKERING, 2013). Essas questões têm sido propostas aos mais diferentes tipos de mídia, a exemplo do cinema, da televisão, da internet e da cultura visual em geral. 


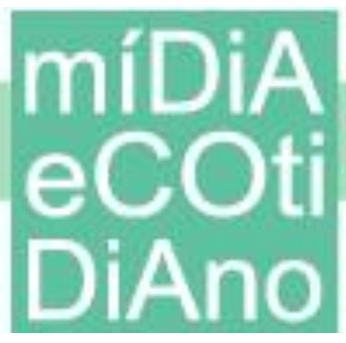

Por exemplo, definindo a midiatização como o processo de mudança cultural resultante da crescente interação com a mídia, Hoskins (2011) indaga sobre suas implicações para a memória. O "giro conectivo" promovido pela internet produziu comunicações instantâneas, relações sociais fluidas, complexas e densas. Para ele, uma nova memória, ancorada pela mídia, foi produzida, uma memória descuidada, já que suportes, redes e próteses digitais passaram a atuar como seu suporte, dispensando o indivíduo da necessidade de lembrar. Por outro lado, a disseminação da mídia trouxe consigo um excesso de memória, materializada em arquivos digitais, aos quais estamos conectados e que são constantemente atualizados. Em um trabalho posterior, Hoskins (2014) afirma que a hiperconectividade sociotécnica demoliu as fronteiras entre as distinções biológicas, sociais e culturais da memória. Nas redes sociais, usuários constroem e reconstroem informações biográficas, compartilham ativamente arquivos audiovisuais, diluindo a fronteira entre o público e o privado, rompendo as distinções entre o total e o contextual, o efêmero e o permanente, o arquivo e a narrativa. Mediatizada através de uma variedade de mídias digitais diárias e de trocas multimodais, a memória libera-se da sua ancoragem com o passado e torna-se dinâmica e configurável.

Hoskins $(2011,2014)$ indica, muito brevemente, quais seriam os contextos aos quais a sua teorização poderia ser aplicável. Acredito que o uso do celular e do tablet enquanto suportes tecnológicos móveis para memória individual, que dispensam o recurso da memorização de dados (contatos, endereços, audiovisual, itinerários de pesquisa na web, etc.) caberiam em seu modelo.

A ideia de que devemos atentar para a construção de bancos de dados de imagens e a construção da memória não é negligenciável. Se a democratização da fotografia no século XX conferiu um papel estruturante ao álbum de família na construção da identidade e de um passado comum do grupo familiar (BOURDIEU, 1965), o que dizer da explosão de álbuns e registros imagéticos nas redes sociais? No entanto, é preciso observar que a compreensão da memória, entendida como um arquivo digital dinâmico, passa bem distante da compreensão da memória enquanto construção social ou coletiva, uma vez que em nenhum momento Hoskins $(2011,2014)$, alude aos "construtores" 


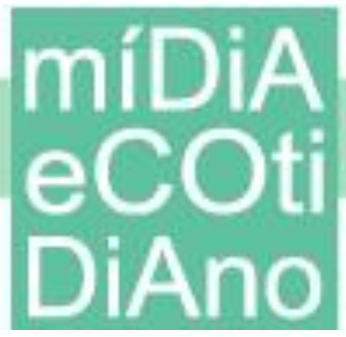

desse arquivo digital. Ao pensar a memória apenas como um sistema de armazenagem ele ignora que o esquecimento e a lembrança são constitutivos do processo de rememoração, assim como disputas entre narrativas. Além disso, é preciso pontuar que outras e importantes questões permanecem em aberto em sua abordagem. Por exemplo: Como a conectividade e a sincronicidade atuam na perspectiva de uma produção coletiva da memória? Elas ampliam as possibilidades de produção de uma memória compartilhada? E quanto à construção social do esquecimento?

Para falar em um enquadramento social da memória, nos termos de Halbwachs (2004) é preciso observar como os determinados grupos sociais constroem, compartilham e se identificam com determinadas narrativas sobre o passado. Dito de outro modo, a mera postagem de dados biográficos, imagens e depoimentos em redes sociais não os constitui enquanto memórias. É preciso indagar quais dados se tornam significativos para diferentes indivíduos e coletividades, que, certamente, fazem usos bem diversos dos recursos tecnológicos aludidos. Parece-me que ignorar essas diferenças é perder de vista a complexidade e riqueza do fenômeno. Ao privilegiar a produção individual, Hoskins elide a perspectiva da institucionalização da memória digital, fundamental para entender o fenômeno da patrimonialização digital (CAVALCANTE, 2007). O patrimônio digital diz respeito tanto aos bens culturais produzidos no mundo digital, como àqueles que passaram por um processo de digitalização (DODEBEI, 2006). A preocupação com a preservação de objetos digitais foi proposta pela Unesco, tanto no ano de 2003, como em 2012. No caso, o olhar arquivístico foi enfatizado, enquanto no último ano a relação entre memória e digitalização foi trazida para o primeiro plano. A perenidade presente na noção de patrimônio digital parece ser uma interessante contrapartida para velocidade e efemeridade das redes sociais, oferecendo uma importante perspectiva de abordagem da relação entre mídia e memória. Em função dessas questões, penso que a abordagem de Hoskins $(2011,2014)$ não nos auxilia a compreender a construção social ou coletiva da memória. Ele apenas alude sobre como as pessoas podem produzir, compartilhar e armazenar informações digitais. 


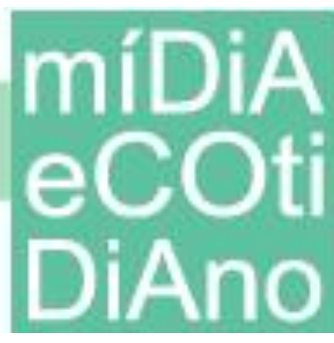

Cabe notar que o estudo dos jogos eletrônicos, que até o presente momento receberam pouca atenção dos pesquisadores dos memory studies, podem fazer avançar na compreensão das relações entre mídia e memória coletiva. De um lado, trata-se da análise da interação com recursos midiáticos multimodais de grande complexidade abertos a um fluxo interativo e constante. O texto multimodal é aquele cujo significado se realiza por mais de um código semiótico (KRESS; VAN LEEUWEN, 1996). Como cada modalidade tem formas e potencialidades específicas de representação, nesses textos, as possibilidades de comunicação de sentidos encontram-se ampliadas e a sua análise mostra-se consideravelmente mais complexa.

De outro lado, alguns desses estudos têm procurado evidenciar como determinadas representações sobre um passado doloroso ou significativo são construídas e compartilhadas através da tecnologia, ou como determinadas redes e mundos virtuais podem ser ressignificados por determinados grupos como espaços de luto referentes a perdas ocorridas no mundo real e virtual. Por último, revelam o papel importante que o grupo profissional dos game designers passou a desempenhar, ao lado de jornalistas e literatos, na produção e difusão de uma memória mediada (THOMPSON, 1998) caracterizada por releituras e narrativas - interativas - sobre um passado marcado por guerras e tragédias, atuando assim como importantes agentes de memória.

\section{Memória coletiva e jogos eletrônicos}

Os usos sociais da memória compreendem práticas como a rememoração e a comemoração (SILVA, 2002). A história das práticas sociais da memória aponta como o Cristianismo medieval, incorporando elementos dos antigos cultos aos antepassados, fortaleceu o laço entre a memória e a morte. São evidências dessa sensibilidade, a criação das orações pelos mortos e dos libri memoriales, onde estavam inscritos os nomes de vivos e mortos, de quem a comunidade deveria guardar memória e por quem deveria rezar. Após a Primeira Guerra Mundial, a comemoração funerária do monumento ao morto se institucionaliza através do túmulo oferecido ao soldado desconhecido (LE GOFF, 2003). 


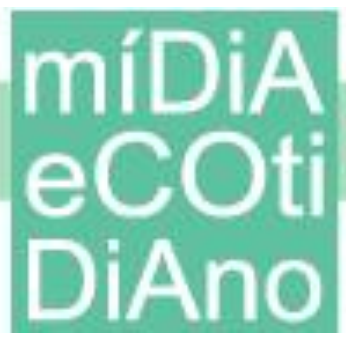

Gibbs (2012) sugere que a disseminação do acesso à internet e a sua integração às práticas comunicativas cotidianas das pessoas permitiu que novas formas de mortuários, rituais e práticas memorialistas se desenvolvessem. Essas práticas têm a característica de estarem menos ligadas à esfera religiosa, e se integrarem mais significativamente à vida cotidiana das pessoas. Nesse contexto, os videogames passaram a ser veículos para a expressão do luto e memorialização dos mortos. Do mesmo modo como fornecem uma contextualização social para a vida, também fornecem um contexto social os cuidados para com a morte. Examinando as práticas memorialistas presentes no jogo World of Warcraft, o autor identifica inúmeros elementos utilizados pelos designers para oferecerem um significado memorial, seja no ambiente simulacional ou na narrativa, a saber: marcos, monumentos, missões e práticas de preservação do avatar.

Analisando a produção coletiva de memória por parte dos jogadores, Mukherjee (2011) destaca as práticas autônomas de produção de dicionários, guias e vídeos sobre a jogabilidade, produzidos e compartilhados ativamente por indivíduos ou comunidades de jogadores. Afirma que a própria prática de jogar, em si mesma, já implica no compartilhamento de lembranças e experiências entre grupos de jogadores.

É importante sublinhar que as pesquisas pautadas no conceito de memória coletiva não se restringem ao nível da narrativa. O processo de produção social das recordações envolve consideração de rituais, comemorações e práticas corporais. As cerimônias comemorativas podem ser descritas como complexas formas de simulações, ações explicitamente representadas como reencenações de atos anteriores. Aqui, a palavra representar significa reapresentar, trazer algo de volta ao presente (CONNERTON, 1999). O jogo de recordar e esquecer pode ser visto como uma corda tensionada entre o presente e o passado e acionada pelas pressões ou demandas da interação social. Isso significa que uma interação lúdica pode fornecer o contexto social para relembrar, comemorar e reencenar o passado. Também é possível falar em esquemas práticos de memória, uma memória cinestésica presente no uso de instrumentos, técnicas e inscrita nos corpos dos jogadores.

Além das micronarrativas individuais, alguns jogos eletrônicos têm revelado potencial de dialogar com importantes narrativas históricas a exemplo da Segunda 


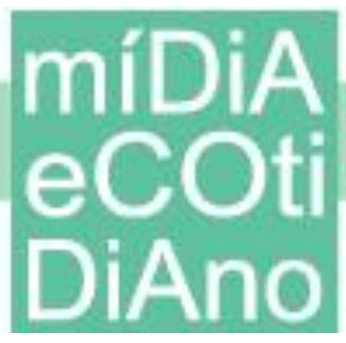

Guerra Mundial, incorporando, segundo Ramsay (2015), conceitos como o "soldadocidadão", a "guerra justa" e a noção da guerra como uma experiência visual. A ideia do "soldado-cidadão" ou do soldado herói já havia sido apontada por Santos (2009) como um dos principais conceitos, em torno dos quais a narrativa do jogo Medal of Honor foi desenhada. Sua dissertação estabelece um paralelo entre o exército norteamericano, a indústria de cinema e a indústria de jogos eletrônicos. Afirma que narrativa do jogo eletrônico Medal of Honor está inserida no contexto de uma mitologia norteamericana que atribui significados heroicos às experiências da guerra, investindo as memórias e relatos dos combatentes de um sentido monumental.

O trabalho de Ramsay (2015) compara Medal of Honor com o jogo Call of Duty. Centrando sua análise no segundo, afirma que o jogo rompe com uma narrativa dominante sobre a Segunda Guerra Mundial, centrada no protagonismo norteamericano e no valor do heroísmo individual. Essa é a perspectiva encontrada em Medal of Honor. Já Call of Duty enfatiza a importância da cooperação entre os soldados para o êxito de uma campanha, valoriza o papel dos inúmeros soldados anônimos e retrata a Segunda Guerra Mundial através dos olhos dos cidadãos-soldados, de soldados desconhecidos e de uma aliança de países. Reposiciona o jogador para assumir e desempenhar o papel dos soldados ingleses e russos, ressaltando a importância da Rússia em vários momentos do conflito, a exemplo da Batalha de Stalingrado.

Gish (2010) sublinha que a série Call of Duty não representa a totalidade da Segunda Guerra Mundial, mas apenas alguns dos seus embates e momentos. Uma das pretensões do jogo é representar o confronto com precisão e realismo. Para atingir esse objetivo, recorreu aos testemunhos dos veteranos, cuja memória é constantemente celebrada nos jogos da franquia. Gish também sustenta que a interação com o jogo promove uma confluência entre a narrativa histórica e a experiência individual do jogador através da reconstrução simulada do conflito. Para ele, as telas do jogo expressam uma memória digital do conflito, permitindo ao jogador uma experiência histórica mais profunda do que a suscitada por outras mídias visuais como o cinema e televisão, que retrataram experiências dramáticas, a saber: a reconstrução da história em seus próprios termos, de maneiras que são significativas e relevantes para cada jogador 
em particular. E isso é possível pela interação lúdica, que reencena os eventos narrados pelos ex-combatentes da Segunda Guerra Mundial. Aqui é possível perceber como a imersão, a agência e a transformação propostos por Murray (2003) atuam como poderosos processos de construção de subjetividade entre os jogadores. Além disso, a estrutura caleidoscópica do computador abre a possibilidade de que os jogadores adquiram uma compreensão mais ampla da complexidade do conflito:

Essa estrutura caleidoscópica traz inúmeras possibilidades para a narrativa; uma das mais atraentes é a capacidade de apresentar ações simultâneas de múltiplas formas [...] No computador podemos dispor de todas as ações simultâneas numa grade e, então, permitir que o interator navegue entre elas [...] Numa história caleidoscópica, com múltiplos pontos de vista, qualquer evento compartilhado pode ter diferentes significados dependendo de esse mesmo acontecimento ser abordado no contexto da vida de um personagem e de outro [...] Vivendo essas histórias entrelaçadas como uma unidade podemos aperfeiçoar a capacidade caleidoscópica de nossas mentes, nossa capacidade de imaginar a vida a parti de múltiplos pontos de vista [...] O poder caleidoscópico do computador permite-nos contar histórias que refletem com maior autenticidade nossa sensibilidade na virada do século. Não acreditamos mais numa realidade singular, numa visão única e integradora do mundo, nem mesmo na confiabilidade de um só ângulo de percepção. No entanto, retemos o desejo humano fundamental de fixar a realidade sobre uma tela apenas, de expressar tudo o que vemos de modo integrado e simétrico. A solução é a tela caleidoscópica, capaz de aprender o mundo como ele se apresenta desde diferentes perspectivas - complexo e talvez incompreensível no final das contas, mas ainda assim coerente. (MURRAY, 2003, p. 155-159)

\section{Assassin's Creed II: ficção, história e memória}

Mukherjee (2011) vê Assassin's Creed como uma metáfora importante para a compreensão do processo de construção da memória dos jogadores na experiência lúdica do videogame. O trabalho de Mukherjee, juntamente a sua ambientação histórica influenciou para que escolhesse Assassin's Creed II como objeto de análise. Também havia o interesse em saber se, dado o seu caráter ficcional, seria possível estabelecer um diálogo com o passado, ainda que imaginário. No entanto, após examiná-lo mais atentamente, encontrei um nível mais complexo de imbricações, pois a narrativa do jogo traz à tona a relação entre memória e história, uma vez que é acessando a memória que o jogador volta no tempo e interage com a história.

Para a análise do jogo, tomei como princípio metodológico que um videogame se apresenta ao jogador como uma intensa experiência audiovisual. Entendendo que certos 


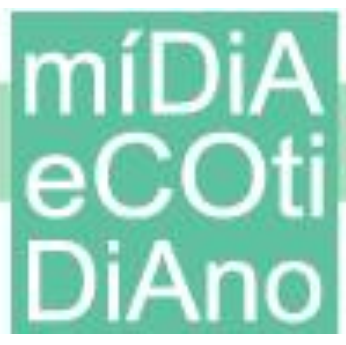

sentidos inerentes à essa experiência poderiam ser mais bem apreendidos apenas em sua forma audiovisual, recorri ao recurso da vídeoetnografia virtual (STRANGELOVE, 2007) ou o que Giddings (2009) chama de uma microetnografia do game play. Em outras palavras, utilizei o computador e o software fraps para efetuar o registro na forma de trechos de vídeo e captura de telas dos principais elementos do jogo a serem analisados. A pesquisa foi conduzida entre agosto de 2014 e agosto de 2015, produzindo um total de 777 gigabytes de dados.

Também me vali da construção de um caderno de campo e do registro da experiência de interação com o jogo, tomando como referência as 18 categorias de investigação propostas por Pereira (2008), a saber: recursos e ganho e experiência; sistema de evolução; descrição do espaço (lugares mapas); associações (aliados e rivalidades); população digital (personagens, monstros, fauna, flora); textos e hipertextos; comunidades e grupos de jogo; narrativa mítica ou passado ficcional (enredo); referência literária da narrativa mítica; apresentação/organização visual da tela e informações; sistemas de interação e comunicação, sistema de orientação (mapa); inventário e itens; comandos; como o jogo é apresentado ao jogador (introdução); jogadores (ativos ou não); e qualidade gráfica. Alguns desses elementos - como grupos de jogadores, chats - não foram aplicáveis à atual análise proposta para este jogo, uma vez que não foi meu objetivo estudar a recepção do jogo pelos jogadores. Além disso, o jogo não possui um modo multiplayer, apesar de ser possível comunicar-se com outros jogadores através do programa da Ubisoft, que gerencia os games da empresa instalados no computador do jogador. Além dessas categorias, julguei importante acrescentar mais quatro: avatar; personagens históricos; fases; e elementos ideológicos. Para manter a coerência aos objetivos aqui propostos, nem todos esses elementos serão abordados no presente artigo. A análise empreendida procurou compreender como imaginário, o fictício e o real existentes no jogo se articularam para construir uma representação do passado (VIANA-TELLES; ALVES, 2016b).

Lançado pela empresa Ubisoft em 2009, o jogo Assasssin's Creed II dá sequência aos eventos do primeiro jogo da série Assassins Creed, retomando o embate entre a Ordem dos Assassinos e a Ordem Templária. O jogo está dividido em 14 fases ou 


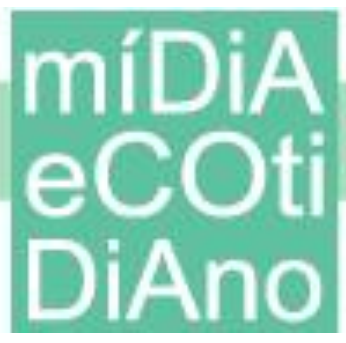

(sequências de memória), visualizáveis como uma linha do tempo nas memórias genéticas de Desmond, como balizas cronológicas, ou seja, temos uma data inicial e uma data final. A primeira inicia-se em 1476 e a última refere-se ao ano de 1499. No enredo, o protagonista Desmond Miles e uma aspirante à assassina, Lucy Stillman, escapam do laboratório de Abstergo, grupo controlado pelos templários, e se dirigem a um esconderijo do grupo dos assassinos onde encontram um novo dispositivo, o Animus 2.0, através do qual Desmond revive as memórias genéticas de outro ancestral, chamado Ezio Auditore da Firenze, que nasceu em 1459 e morreu em 1524. O pai de Ezio e seus irmãos são vítimas de conspiradores que os acusam de trair a cidade de Florença e são executados em praça pública. Após uma tentativa fracassada de salvar seus familiares, Ezio escolta sua mãe e sua irmã para uma propriedade da família, a Vila Auditore, comandada por seu tio, Mário, que o convence a ficar e lutar contra os conspiradores templários, seus antagonistas durante o jogo. As investigações sobre a conspiração levam Ezio a descobrir que a morte de seus familiares era parte de um plano ainda mais amplo, que tinha como objetivo eliminar a família Medici. Falha em salvar Giuliano de Medici, mas consegue escoltar Lourenço em segurança e, assim, uma aliança é forjada entre eles. Na fase 5, conclui a eliminação dos assassinos dos Medici e descobre a existência de uma rede de conspiração que se estende até o Vaticano. A trama, que tem início em Florença, é apenas um capítulo de uma narrativa mais ampla que leva ao questionamento dos próprios mitos bíblicos. Ela é revelada em um vídeo chamado "A verdade", cujas partes são montadas à medida que Ezio desvenda os enigmas dos glifos e explicada pela entidade chamada Minerva, que ele encontra no final do jogo.

\section{Análise da narrativa}

Para compreender a estrutura narrativa do jogo, Stobbart (2013) inspira-se no trabalho de Gennete (1995). O jogo é pensado como uma estrutura narrativa complexa, dotada de múltiplos níveis temporais, a saber: a narrativa central de Desmond Miles e a narrativa subordinada de Ezio Auditore da Firenze. Enquanto continuação do tema de Assassin's Creed I, Assassin's Creed II avança na história de um trabalhador do século XX, chamado Desmond Miles, raptado pela organização dos templários que explora 


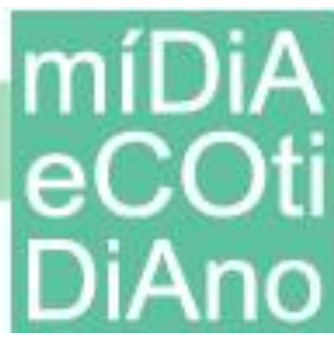

suas memórias genéticas, com a utilização de uma tecnologia chamada animus. Através da interação com o animus, Desmond descobre que seu ancestral, Altair, pertenceu à uma seita medieval xiita de assassinos, que estava envolvida em uma disputa com os templários pelo controle do planeta. Ou seja, enquanto a história de Desmond se passa no presente do século XXI, a narrativa do seu ancestral se dá em um passado histórico distante. Em Assassin's Creed II, Desmond é libertado do laboratório dos templários e é conduzido ao laboratório dos assassinos, onde interage com um aparelho mais sofisticado, o animus 2.0. Através dessa interação, ele acessa as memórias de outro ancestral que viveu na Florença renascentista, chamado Ezio.

Apesar da narrativa de Ezio ocupar a maior parte do jogo, ela é emoldurada pela narrativa de Desmond. Trata-se, portanto, de uma história dentro de outra história, a exemplo do que acontece tipicamente na estrutura de uma fábula. Com base nessa estrutura narrativa, inúmeros recursos, a exemplo da interface visual do jogo, ganham sentido ao mesmo tempo em que o nível de imersão e interação com o jogo é ampliado, à medida que determinadas informações, que dão significado ao jogo (mapas, personagem, reanimação, etc.), são disponibilizadas dentro do mundo do jogo. Esse recurso, que tende a reforçar a experiência de adesão ao universo discursivo do jogo, ao invés de problematizá-lo, é exponencialmente potencializado pelas características midiáticas dos jogos eletrônicos. A narrativa de Desmond é uma narrativa que se passa em um plano diegético, estruturalmente superior, enquanto a narrativa de Ezzio é metadiegética, uma narrativa dentro da narrativa. Há também outro nível narrativo, a narrativa de Altair, que atravessa todos os níveis narrativos, pois a aprendizagem de Ezio sobre a vida de Altair acrescenta um terceiro nível temporal à narrativa. A autora sustenta que a estrutura narrativa de Assassin's Creed II baseia-se no uso de analepse, ou seja, o aparecimento na sequência temporal da narrativa de um evento que ocorreu mais cedo do que o ponto na história onde estamos em um dado momento. A tipologia de Genette (1995) menciona dois tipos de analepses - as internas e as externas - em função do nível de narrativa em que ocorrem. A externa se dá fora da diegese, proporcionando à narrativa informações; a interna ocorre dentro da mesma diegese, ainda que num momento anterior, com a mesma função. Desse modo, a narrativa Ezio pode ser 


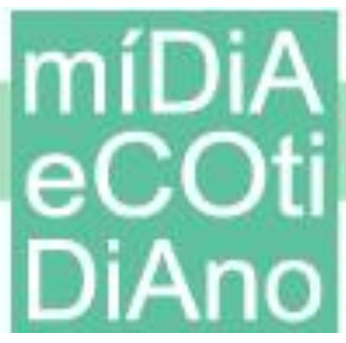

pensada, no nível estrutural, como uma série de analepses externas, como dependente, ocorrendo dentro da narrativa Desmond. Essas várias camadas narrativas se conjugam na experiência do jogo, contribuindo para ampliar a experiência de imersão em um complexo universo ficcional.

\section{O ficcional, o imaginário e o histórico}

O problema das representações do passado entre História e no jogo Assassin's Creed II vem sendo discutido por uma gama bastante diversa de intelectuais, a exemplo de jornalistas e historiadores. Para jornalistas como Kaylan (2010) e Stuart (2010), o jogo aproxima o jogador da compreensão e vivência da História. O primeiro afirma que a interatividade presente no jogo traz uma experiência do passado qualitativamente mais rica que o cinema ou o turismo, sendo capaz de reviver o sentido da História. Já Stuart (2010) considera que os jogos eletrônicos são o melhor meio para a produção da ficção histórica. Os recursos interativos presentes nesses jogos permitem ultrapassar a exibição e atingir a experimentação. De outro lado, o recurso à História por parte dos produtores de jogos eletrônicos seria uma resposta ao esgotamento dos temas de ficção científica nesse segmento: o uso de referências históricas pode melhorar a atmosfera do jogo e torná-lo mais dramático e emocionante para o público. No entanto, é preciso distinguir entre o uso da ambientação histórica para jogabilidade simples, enquanto cenário ou tema para que uma ação de desenrole, e os níveis mais complexos, que oferecem ao jogador a compreensão dos problemas de um determinado contexto histórico. Um importante ponto do artigo de Stuart (2010) é situar o jogo Assassin's Creed II no bojo das críticas pós-modernas ao pensamento histórico, em sua relativização do estatuto da verdade. O jogo seria capaz de promover uma mistura de ficção científica, documentação e exploração do passado. Nos termos propostos por Kee (2011), para análise das concepções de História presentes em videogames, o jogo se alinha com a perspectiva de uma História pós-moderna.

Dow (2013), historiador e especialista em Renascimento, concorda que a Florença simulada pelo jogo Assassin's Creed II não é uma recriação fidedigna da Florença do século XV. Identifica diversos anacronismos no plano da arquitetura apresentada pelo 


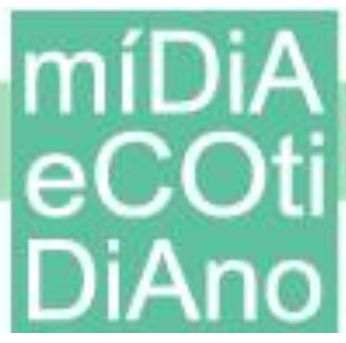

jogo, que retrata determinados edifícios que teriam sido construídos em períodos anteriores ou posteriores ao século no qual se passa a narrativa. Contudo, para ele, o anacronismo presente no jogo é positivo, por aproximar os jogadores da experiência do cotidiano da Florença atual, possibilitando que diversos monumentos vistos no jogo sejam reconhecidos em uma futura visita à cidade. A simulação do jogo não remete o jogador à dimensão do real, mas à dimensão do hiper-real existente na cidade atual, uma vez que na Florença "real" também existem elementos de simulação. Desse modo, o jogo pode "vazar" para a realidade e influenciar o modo como os jogadores experimentam a atual cidade de Florença. Esse "vazamento" é encontrado nos relatos de pessoas que, ao ter contato com a cidade após interagirem com o jogo, tiveram uma experiência de reconhecimento e familiaridade, norteada pelas suas vivências digitais, um fenômeno análogo à experiência de Halbwachs com a literatura. Dow (2013) sugere que em vez de criticar o que são, aos olhos modernos, imprecisões evidentes no jogo, seria melhor imaginar como as pessoas do século XV poderiam ver esses monumentos. No Renascimento, o sentido e o imaginário associados aos monumentos eram mais importante que a sua datação. Para além das aporias teóricas da historiografia, cabe sublinhar que o trabalho de reconstrução, ainda que aproximada, da Florença renascentista e de seus monumentos contribui para a sua patrimonialização digital.

É forçoso notar que, ao restringir sua análise ao problema da precisão histórica dos elementos simulacionais existentes no jogo, Dow (2013) ignora aspectos da narrativa e do game play que são importantes para a própria questão que propôs. No entanto, os trabalhos de Stobbart (2013) e Svensson (2013) sublinharam a importância do banco de dados textuais e audiovisuais conhecido como animus 2.0 para a compreensão do jogo. Enquanto Stobbart (2013) situa o animus 2.0 como oferecendo uma nova camada diegética, Svensson (2013) o considera como um dispositivo responsável por oferecer informações historicamente verídicas.

O animus 2.0 pode ser considerado como uma grande biblioteca, cujo conteúdo vai sendo construído à medida que o jogador interage com a sequência narrativa. As entradas de dados desse sistema são acionadas todas as vezes que o personagem explora o cenário e se depara com algum monumento histórico, ou personagem de época. As 


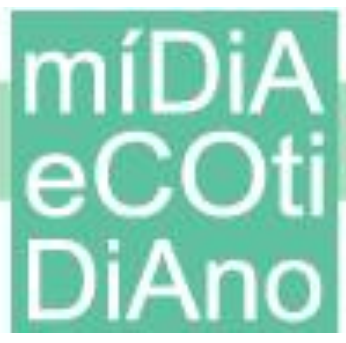

informações são exibidas em slides que narram, em detalhes, o percurso histórico que levou à construção e modificação de determinada edificação até o século XV, seus arquitetos, detalhes estéticos, etc., assemelhando-se ao tipo de texto ou de discurso que poderia ser recebido numa enciclopédia ou exposição de história da arte, feita por um especialista da área. Também é possível encontrar alusões aos usos simbólicos de determinada edificação, mais precisamente às suas relações com as instituições políticas e conflitos da época e, sobretudo, inúmeras biografias. Portanto, além do nível da simulação e da narrativa, essa base de dados acrescenta uma dimensão propriamente textual ao videogame transformando-o em um discurso multimodal altamente complexo.

Penso que seja central para a compreender como o nível do real, do imaginário e do ficcional são articulados pelo jogo. Se, do ponto de vista da estética do jogo, a adição de textos históricos tem o efeito de oferecer mais realismo ao ambiente de época, alimentando o imaginário sobre o período renascentista que o jogo procura recriar, também acrescenta um novo nível diegético ao jogo, que ficcionalmente passa a ser remetido à própria narrativa historiográfica, ainda que os textos presentes no jogo atuem no sentido de remeter à ficção e não à realidade em si. Além da historicidade anacrônica e hiper-realista, proporciona um outro tipo de historicidade muito próxima a que é encontrada em um tradicional livro didático de História. Contudo, não é possível considerá-lo como espaço no qual as informações verídicas do jogo podem ser acessadas, uma vez que também há dados ficcionais no animus. Em geral, esses elementos ficcionais se referem à caracterização de personagens como pertencentes aos templários ou aos assassinos. Portanto, é preciso atentar para o fato de que, tanto os personagens fictícios quanto os verídicos, possuem biografias, que são postas lado a lado sem distinção. Por exemplo, se o papel desempenhado por Leonardo da Vinci na narrativa do jogo é ficcional, pois ele é retratado como um inventor membro da seita dos assassinos, as informações que a biblioteca do animus disponibiliza sobre a sua biografia são verídicas. Além disso, um notável grau de precisão histórica pode ser encontrado nos textos sobre prédios e monumentos simulados pelo jogo como pode visto na figura abaixo. 


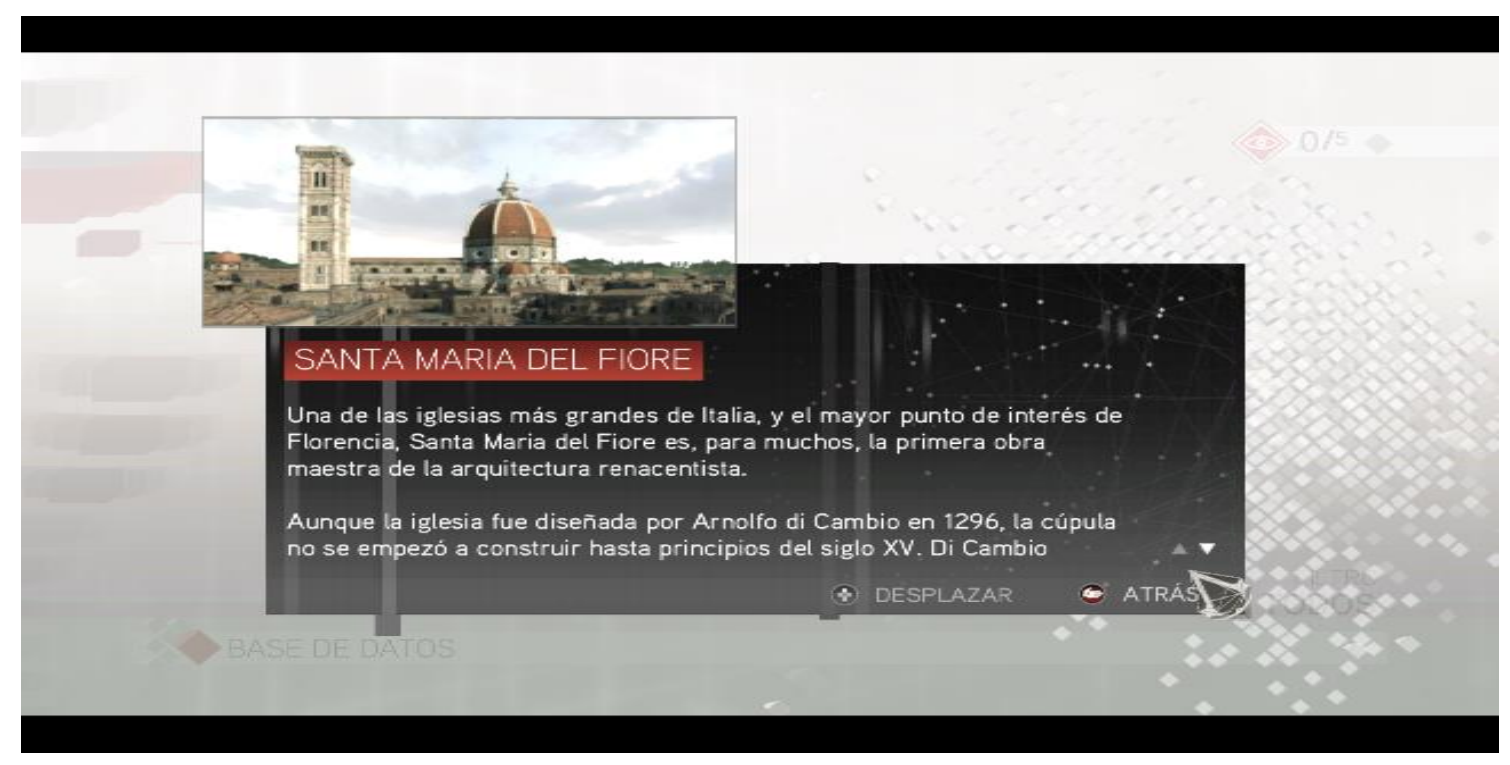

Figura 1. Captura de Tela da base de dados de A.C.II.

Fonte: feita em 21 de agosto de 2014 pelo autor.

A Conspiração Pazzi é a referência literária e histórica da narrativa ficcional do jogo. O nome da família Pazzi ganhou notoriedade através dos sucessos militares da Primeira Cruzada. Na Divina Comédia, dois membros da família Pazzi são colocados no inferno. No entanto, foi através do complô para assassinar os irmãos Medici, que o inscreveu na história da Itàlia, nas artes e na memória de Florença. Em 1478, os Pazzi eram banqueiros rivais dos Médici, que contavam com a proteção do pontífice Sisto IV. Os Pazzi, com a cumplicidade do arcebispo de Florença, decidiram assassinar os irmãos governantes na catedral metropolitana. Tiveram sucesso com Giuliano, mas Lorenzo, ainda que ferido, conseguiu salvar-se, refugiado na sacristia. A reação do povo e das tropas leais a Lourenço foi imediata e a conspiração foi combatida com a mais extrema violência: o arcebispo foi enforcado e dependurado em uma das janelas do Palazzo Vecchio, ainda vestido com suas roupas cerimoniais, enquanto os demais conspiradores, agarrados pela multidão e enforcados ou esquartejados. Essa narrativa, que ainda é ouvida pelos turistas que visitam em Florença a Basílica de São Lourenço ou o túmulo dos Médici, tem sido exaustivamente retratada na literatura. Esse interesse é compreensível, pois os Médici tiveram grande importância, não apenas como patronos das artes, mas na economia e na política mundial. Entronizaram dois papas e 


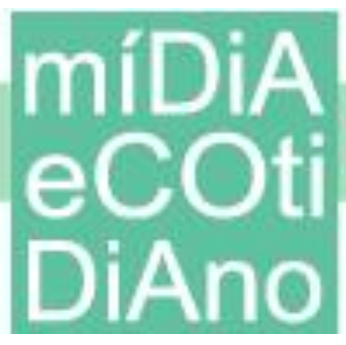

constituíram importantes linhagens da realeza europeia. Além disso, intelectuais e artistas como Maquiavel, Leonardo, Poliziano e Pierpalo Mazoni foram testemunhas do atentado (FORTES, 2010). Estavam envolvidos na conspiração: Francesco Salviati, Conde Girolamo e Cardeal Raffaele Siario, Francesco e Jacopo de Pazzi, Gian Battista Montesecco, Lorenzo Giustini, Jacopo Bracciolini, Marsílio Ficino, Gian Francesco de Tolentino e o Papa Sisto IV (SIMONETTA, 2009).

Gostaria de descrever o contexto histórico da Conjuração Pazzi com mais amplitude e rigor. Na renascença, as cidades-Estado italianas estavam controladas, em diferentes níveis de tirania, por dinastias familiares: os Sforza, em Milão e na Lombardia; os Médici, em Florença e Toscana; e os Aragão, em Nápoles. A construção da Capela Sistina, e várias das obras de arte que lá se encontram, está diretamente relacionada com a Conspiração Pazzi. Quando Francesco Sforça tornou-se Duque de Milão, estabeleceu em 1454 a Paz de Lodi com Florença, oferecendo proteção militar a Cosme de Médici, em troca de auxílio financeiro. Esse acordo trouxe estabilidade à península italiana e prosperidade para Milão e Florença (BURCKHARDT, 1991).

Devido ao contexto de embates políticos e militares frequentes, o recurso ao ardil e à astúcia era um fenômeno recorrente. Para eliminar um inimigo poderoso em uma época dominada pela tecnologia militar da lâmina, era preciso esconder suas armas, aproximar-se furtivamente e colocar-se na distância exata para usar as armas, condição propiciada pelo espaço das igrejas. O assassinato de Giuliano Médici foi antecedido pela morte de um aliado poderoso, o Duque de Milão. Galeazzo Maria Sforza foi brutalmente trucidado a facadas por três jovens na Igreja de Santo Stefano em Milão em vinte e seis de dezembro de 1476, aos trinta e dois anos. Dois dos assassinos foram imediatamente mortos, mas um deles conseguiu momentaneamente escapar desaparecendo em meio à multidão (SIMONETTA, 2009).

$\mathrm{Na}$ época, esse tipo de atentado era praticado por jovens ricos que viam no assassinato uma forma sagrada de promoção da justiça. O assassino sobrevivente, Girolamo Olgiati, tinha vinte e três anos, era um letrado e erudito descendente de uma próspera família de Milão. Leitor do escritor romano Salústio, seu livro de cabeceira era A Conspiração Catilina. Acreditava que era preciso seguir o exemplo dos romanos para 


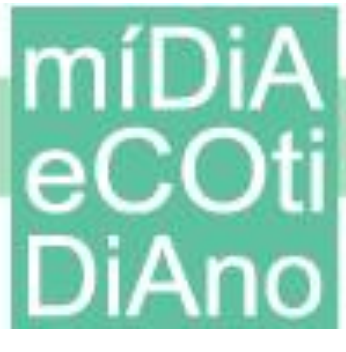

libertar o país, assassinando os tiranos. Foi discípulo de Cola Montano, um humanista a quem Galeazzo mandou chicotear em praça pública sob acusação de estupro. Girolamo não tinha medo da morte, mas temia o esquecimento, uma vez que considerava que a sua fama perduraria após a sua morte. De fato, após ter sido encontrado, foi esquartejado. A sua motivação era, portanto, ideológica. Já os outros dois assassinos de Galeazzo, Giovanni Andrea Lampugnanni e Carlo Visconti, foram motivados por razões afetivas: A irmã de Visconti e a mulher de Lampugnani tinham sido estupradas por Galeazzo e por todos os membros da sua comitiva (SIMONETTA, 2009, p. 33).

Com base no exposto acima, é necessário admitir que existe uma verossimilhança entre a biografia do personagem Ezio Auditore, um jovem que se tornou assassino pelo desejo de vingar a morte de entes queridos por poderosos corruptos e restaurar a honra familiar, e a biografia de jovens italianos que, na Itália renascentista, praticaram assassinatos furtivos contra tiranos poderosos e inimigos políticos. De fato, o enredo do jogo põe o avatar no coração dos eventos sangrentos desencadeados pela Conspiração Pazzi, que Ezio descobre ter sido a responsável pela execução de sua família. Em função disso, Ezio protege e salva Lourenço de Médici, além de partir no encalço dos seus inimigos. O jogo reconstrói, reapresenta a cena da guerra civil provocada pelo atentado Pazzi, mostra a morte de Giuliano Médici e a execução do arcebispo, faz o jogador ver o corpo dele a balançar dependurado publicamente nas paredes do edifício. Ele e os demais conspiradores são ficcionalmente mortos pelas mãos de Ezio, em sua caçada até o Papa. Mas, nesse ponto, o jogo ficcionalmente substitui a figura do Papa Sisto IV, por Rodrigo Bórgia. Desse modo, Ezio pode ser pensado como a representação da população florentina e como a mão da vendeta Médici, em sua violenta reação contra os Pazzi.

Em função dos elementos acima descritos, sustento que o jogo Assassin's Creed II não trata do Renascimento como processo histórico. Ele se refere a um lugar no espaço e no tempo do Renascimento: Florença. Ele dialoga com a história, a memória e o imaginário sobre a Conspiração Pazzi e, mais precisamente ainda, com o trabalho de Simonetta (2009), que foi contratado como consultor pelos desenvolvedores do jogo. Em seu livro, ele analisa documentos, retratos, pinturas e biografias relacionadas com o 


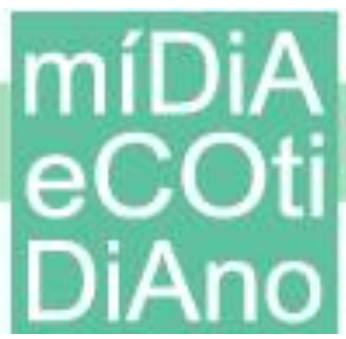

evento e com período histórico. Constrói os conspiradores como personagens envolvidos numa trama. O jogo reproduz essas mesmas informações, além de oferecer simulações digitais dos principais edifícios de Florença e de algumas cidades italianas no final do século XV. No videogame, o trabalho de paleografia empregado por Simonetta (2009), para decifrar documentos, aparece na forma das chamadas páginas do Codex. Já a interpretação das obras de arte e a sua relação com o contexto político da época é transportada para o jogo na forma dos "glifos", enigmas a serem resolvidos, que tomam como base quadros e representações visuais de personagens históricos. Ao mostrar o sofrimento de Ezio pela execução injusta de sua família, o enredo do jogo permite que o jogador compreenda o conceito de conspiração, se identifique emocionalmente com a perda sofrida por Lourenço de Médici e compreenda a reação de violência e indignação da população de Florença para com os conspiradores Pazzi.

Dos aspectos ideológicos, possíveis de serem discutidos, farei menção a apenas um deles: a dimensão política. O enredo do jogo Assassin's Creed II posiciona o jogador e o avatar ao lado dos governantes de Florença. O desenvolvimento da narrativa leva a uma inevitável aliança entre Ezio e Lourenço de Medici, pois seus inimigos são os mesmos. Ezio e Lourenço são unidos pelos crimes políticos de seu tempo: ambos sofreram perdas familiares em função deles. Desse modo, o enredo situa o assassino Ezio ao lado da ordem, dos poderes instituídos, e do progresso histórico, apesar do lema dos assassinos sugerir a adoção de uma posição anárquica. Os assassinatos cometidos por Ezio são mortes realizadas a serviço do Estado, como faria um soldado em tempo de guerra, ou um agente secreto cumprindo a sua missão. São assassinatos políticos. Esse aspecto confere um sentido muito preciso à violência retratada no jogo. Trata-se da representação da violência e do modus operandi da violência inerente a um período histórico. O avatar deve concentrar-se unicamente na eliminação dos alvos apontados pelo enredo, uma vez que a eliminação de meros transeuntes leva o jogador a ser punido severamente com a interrupção do jogo. 


\section{míDiA

\section{Considerações finais}

O título deste artigo é uma provocação. A intenção foi a de levar o leitor a indagar sobre as relações entre memória coletiva, narrativas interativas e simulação digital. Isso implicou em reconhecer o insight de Murray (2003), que propôs o computador e as mídias ou espaços digitais como um importante vetor do desenvolvimento de uma longa tradição narrativa e sugeriu importantes ferramentas para apreender a especificidade desse fenômeno, a exemplo dos conceitos de interação, imersão e transformação. Proponho que para o aprofundamento da compreensão sobre as relações entre jogos digitais e História e memória coletiva é preciso atentar, em específico, para a perspectiva narratológica da análise dos jogos e, de modo mais amplo, para a investigação sobre as estruturas narrativas. Contudo, o título também traz a necessidade de criticar a proposta de Murray, uma vez que ela limitou a investigação sobre a ampliação dos suportes narrativos humanos unicamente à esfera ficcional. Ao fazê-lo, mutilou a apreensão do seu potencial comunicativo mais amplo, a saber, a possibilidade para compartilhar os conhecimentos científicos, as narrativas históricas, as tradições e a memória coletiva, bem como o seu potencial para a formação de comunidades e identidades coletivas. Considero que é essa a principal questão. O que se passa na esfera ficcional pode ser visto como apenas um caso particular desse fenômeno mais amplo. Além disso, nos dias atuais, também é necessário expandir o leque de investigação e apontar a disseminação dessas mesmas possibilidades comunicativas para outros dispositivos, além do computador, como consoles de videogames, smartphones, e outros dispositivos móveis. O "giro conectivo" promovido pela internet criou a possibilidade de usufruir de um fluxo contínuo de compartilhamento e troca de narrativas, imagens e dados complexos. Sustento que o estudo dos jogos eletrônicos pode fazer avançar na compreensão das relações entre mídia e memória coletiva, uma vez que esses suportes mobilizam recursos midiáticos multimodais de grande complexidade. O conceito de multimodalidade, parece-me mais preciso do que a noção de "enciclopedismo" empregado por Murray (2003) para descrever os recursos semióticos empregados pelos videogames. 


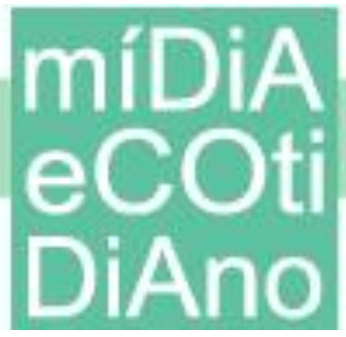

Também acredito que o investigador precisa olhar com interesse para o papel do grupo dos trabalhadores que atuam na produção de videogames, uma vez que esses passaram a desempenhar, ao lado de jornalistas e literatos, o importante papel de agentes de memória.

Narrativas e simulações são formas canônicas de suportes para a recordação social. Procurei demonstrar que, através das narrativas compartilhadas e simulações digitais e interativas, jogos como Assassin's Creed II não apenas reúnem práticas diegéticas e miméticas complexas, mas convidam o jogador a interagir e reencenar essas memórias. Nisto reside o entendimento de como os videogames atuam como suportes para a memória coletiva e como contêm e estimulam o compartilhamento de representações e imagens e de um imaginário sobre o passado. Trata-se de novas práticas e sensibilidades, de maneiras de apropriação de representações coletivas, que oferecem importantes contribuições para a construção da memória coletiva. Uma interação lúdica pode fornecer não apenas o contexto social para relembrar, comemorar e reencenar o passado de um modo específico, mas pode oferecer a possibilidade caleidoscópica de fazê-lo de diferentes modos ou variadas perspectivas e, nesse ponto, parece ser mais sensível ao problema da alteridade. Além disso, os videogames também passaram a ser veículos para a expressão do luto e memorialização dos mortos, quando os designers lançam mão, seja no ambiente simulacional ou na narrativa, de marcos, monumentos, missões e práticas de preservação do avatar. Porém, no plano individual, a própria prática de jogar leva ao compartilhamento de lembranças e experiências individuais entre grupos de jogadores.

Procurei demonstrar como alguns jogos eletrônicos têm revelado potencial de dialogar com importantes narrativas históricas, a exemplo da Segunda Guerra Mundial e do Renascimento. Argumentei que no jogo Assassin’s Creed II não é possível encontrar uma narrativa do Renascimento como processo histórico. Contudo, o videogame retrata a memória e o imaginário sobre a Conspiração Pazzi, além de oferecer simulações digitais dos principais monumentos de Florença e de algumas cidades italianas no final do século XV. Além disso, o enredo e a e experiência do game play, aliados à interação com a simulação digital permitem que jogador possa experimentar e compreender a 


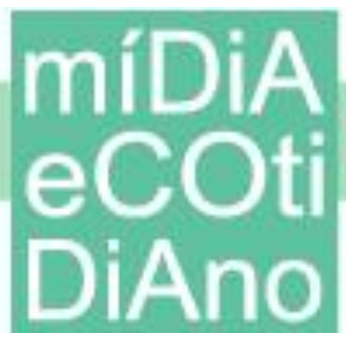

lógica das conspirações e dos assassinatos políticos descritos pela historiografia do Renascimento.

Nos exemplos trazidos, tratei exclusivamente de jogos desenhados voltados para o mercado de videogames. Os jogos desenvolvidos com propósito educativo merecem uma análise particular e podem evidenciar conexões ainda mais substantivas com percursos e práticas mnemônicas, que envolvem narrativas e práticas lúdicas: Narra-se lá, joga-se aqui. Se a simulação não é estranha à memória, o simulacro digital parece enriquecê-la ainda mais com materiais oriundos da multimodalidade, além de vivificá-la ou intensificá-la através da experiência da imersão proceduralmente construída.

Nos videogames aludidos, demonstrei a presença de referências aos sentidos ou funções classicamente atribuídas aos trabalhos da memória coletiva: simulação, narrativa, monumento, luto, comemoração, rememoração e patrimônio, esta última encontrada no jogo Assassins Creed II, jogo que promove a patrimonialização digital da cidade de Florença. À semelhança do que aconteceu com Halbwachs e a sua experiência de reconhecimento norteada pelas suas memórias literárias, o relato de Dow (2013) mostra como a vivência do passado reconstruído no jogo Assassin's Creed II irrompeu na consciência de alguns estudantes de História que, após passarem pela experiência do jogo e visitaram Florença, assumindo a forma de lembrança, reconhecimento e familiaridade.

Os recursos multimodais presentes em determinados tipos de jogos eletrônicos ampliam as possibilidades de compartilhamento da memória. A análise do jogo Assassin's Creed II demostrou como a tecnologia digital permite que uma mesma representação sobre o passado possa ser expressa através de audiovisual, texto, simulacro e narrativa. Em função disso, é ainda mais necessário falar, nos termos propostos por Halbwachs, em uma memória socialmente construída.

Acredito que esse é um debate bastante profícuo que muito pode ganhar com o desenvolvimento de estudos que se desloquem da análise do conteúdo das mídias para o entendimento dos seus usos. Na perspectiva de Halbwachs, isso significaria compreender - e esse parece ser um promissor programa de pesquisa - como é 
construído o enquadramento social da memória dos jogadores, designers, programadores e outros grupos sociais.

\section{Referências}

AQUINO, T. de. Suma teológica. São Paulo: Loyola, 2004.

BARTLETT, F. C. Remembering: a study in experimental and social psychology. Cambridge: Cambridge University Press, 1977.

BOURDIEU, P. Essai sur lês usages sociales de la photographie. Paris: Minuit, 1965.

BURCKHARDT, J. A cultura do Renascimento na Itália: um ensaio. Brasília: UnB, 1991.

CALVACANTE, L. E. Patrimônio digital e informação: política, cultura e diversidade. Encontros Bibli., UFSC, v. 23, p. 152-170, 2007.

CONNERTON. Como as sociedades recordam. 2 ed. Oeira: Celta, 1999.

CASSAR, R. God of war: a narrative analysis. Eludamos - Journal for Computer Game Culture, [s.1.], v. 7, n. 1, p. 81-99, 2013. Disponível em: <http://www.eludamos.org/index.php/ eludamos/article/view/vol7no1-5> Acesso em: 10 fev. 2014.

CRUZ, M. (Org.). Hacia dónde va el passado: el porvenir de la memoria en el mundo contemporáneo. Barcelona: Paidós, 2002.

DODEBEI, V. Patrimônio e memória digital. Morpheus - Revista Eletrônica em Ciências Humanas, v. 4, n. 8, p. 1-21, 2006. Disponível em: <http://www.seer.unirio.br/index.php/ morpheus/article/view/4759>. Acesso em: 20 jun. 2015.

DOSSE, F. A História. São Paulo: EDUSC, 2003.

DOW, D. N. Historical veneers anachronism, simulation, and art history in Assassin's Creed II. In: KAPELL, M. W.; ELLIOTT, A.B. R. Playing with the past: digital games and the simulation of history. New York/London: Bloomsburry, 2013.

FORTES, S. Quattrocento. Rio de Janeiro: Record, 2010.

GIBBS, M. et al. Tombstones, uncanny monuments and epic quests: memorials in world of warcraft. Game Studies - The International Journal of Computer Game Research, [s.l.], v. 12, issue 1, Sept. 2012. Disponível em: <http://gamestudies.org/1201/articles/gibbs_martin>. Acesso em: 18 jun. 2013.

GENETTE, G. Discurso da narrativa. 3 ed. Lisboa: Vega, 1995.

GIDDINGS, S. Events and collusions: a glossary for the microethnography of videogame play. Games and Culture - A Journal of Interactive Media, [s.1.], v. 4, n. 2, p. 144-157, 2009.

GISH, H. Playing the Second World War: call of duty and the telling of history. Eludamos, [s.l.], v. 4, n. 2, p. 167-180, 2010. Disponível em: <http://www.eludamos.org/index.php/ eludamos/article/viewArticle/vol4no2-4/175>. Acesso em: 20 jun. 2015.

KEE, K. Computerized history games: narrative options. Simulation \& Gaming, [s.1.], v. 42, n. 4, Aug. 2011, p. 423-440. Disponível em: <http://sag.sagepub.com/content/42/4/423>. Acesso em: 20 set. 2014.

HALBWACHS, M. A memória coletiva. São Paulo: Vértice/Revista dos Tribunais, 1990. 
. Los marcos sociales de la memoria. Caracas: Anthropos, 2004.

HOSKINS, A. Media, memory, metaphor: remembering and the connective turn. Parallax, [s.1.], v. 17, n. 4, p. 19-31, 2011. Disponível em: <http://www.tandfonline.com/doi/abs/ 10.1080/13534645.2011.605573>. Acesso em: 26 jul. 2015.

The mediatization of memory. In: LUNDBY, K. (Org.). Mediatization of communication. Berlin: De Gruyter Mouton, 2014.

KAYLAN, M. Time travel gets closer to reality. The Wall Street Jounal, [s.1.], 12 Jan. 2010. Disponível em: <http://online.wsj.com/news/articles/SB1000142405274870393940 4574568220649184090>. Acesso em: 20 jun. 2013.

KEE, K. Computerized history games: narrative options. Simulation \& Gaming, [s.1.], v. 42, n. 4, p. 423-440, Aug. 2011. Disponível em: <http://sag.sagepub.com/content/42/4/423〉. Acesso em: 20 set. 2014.

KEIGHTLEY, E.; PICKERING, M. (Orgs.). Research methods for memory studies. UK: Edinburgh University Press, 2013.

KRESS, G.; VAN LEEUWEN, T. Reading images: the grammar of visual design. London; New York: Routledge, 1996.

LE GOFF, J. História e memória. 5 ed. Campinas: Editora da Unicamp, 2003.

LEROI-GOURHAN, A. O gesto e a palavra: memória e ritmos. Lisboa: Edições 70, 1987.

LÉVY, P. A ideografia dinâmica: rumo a uma imaginação artificial? São Paulo: Loyola, 1998.

MUKHERJEE, S. Re-membering and dismembering: memory and the (re)creation of identities in videogames. Games and Philosophy Conference. 2011. Disponível em: <http://www.academia.edu/532662/Re-mbering_and_Dismembering_Memory_and_the_

Re_Creation_of_Identities_in_Videogames>. Acesso em: 10 jun. 2013.

MURRAY, J. H. Hamlet no Holodeck: o futuro da narrativa no ciberespaço. São Paulo: Unesp, 2003.

OLIVEIRA, L. R. Cardoso de. As categorias do entendimento humano e as noções de tempo e espaço entre os nuer. Série Antropologia, Brasília, DF, n. 7, 137, p. 02-15, 1993.

PEREIRA, V. A. Na lan house, porque jogar sozinho não tem graça: estudo das redes sociais juvenis on e offline. 2008. Tese [Doutorado] - Rio de Janeiro, UFRJ, Programa de PósGraduação em Antropologia Social - Museu Nacional, 2008.

PINHEIRO FILHO, F. A noção de representação em Durkheim. Lua Nova, São Paulo, n. 61, p. 139-155, 2004.

RAMSAY, D. Brutal games: call of duty and the cultural narrative of World War II. Cinema Journal, [s.1.], v. 54, n. 2, p. 94-113, 2015. Disponível em: <http://muse.jhu.edu/content/ crossref/journals/cinema_journal/v054/54.2.ramsay.html >. Acesso em: 20 jan. 2016.

RICOEUR, P. A memória, a história, o esquecimento. Campinas: Editora da Unicamp, 2007.

ROEDIGER, H. L.; WERTSCH, J. V. Creating a new discipline of memory studies. Memory Studies, [s.l.], 1, vol. 1, p. 9-22, 2008.

QUEAU, P. O tempo virtual. In: PARENTE, A. (Org.). Imagem-máquina: a era das tecnologias do virtual. Trad.: Rogério Luiz et al. Rio de Janeiro: Ed. 34, 1993. 
SANTOS, C. B. M. Medal of honor e a construção da memória da Segunda Guerra Mundial. 2009. Dissertação [Mestrado em História] - Universidade Federal Fluminense, Rio de Janeiro, 2009.

SANTOS, M. S. dos. Memória coletiva e teoria social. São Paulo: Anna Blume, 2003.

SHAFFER, D. W. How computer games help children learn. New York: Palgrave, 2007.

SIMONETTA, M. A conspiração contra os Médici: arte e traição do domo de Florença à Capela Sistina. Rio de Janeiro: Record, 2009.

STRANGELOVE, M. Virtual video ethnography: towards a new field of internet cultural studies. Interin, Universidade Tuiuti do Paraná, v. 3, n. 1, p. 1-20, 2007. Disponível em <http://interin.utp.br/index.php/vol11/article/view/127/113>. Acesso em: 3 mar. 2013.

STOBBART, D. Playing with fiction: ludology and the evolution of narrative in videogames. [s.d.]. Disponível em: <http://www.inter-disciplinary.net/critical-issues/wp-content/uploads/ 2013/05/stobbartvideopaper.pdf >. Acesso em: 20 jun. 2014.

STUART, K. Assassin's Creed and the appropriation of history. The Guardian, London, 19 nov. 2010. Disponível em: <http://www.theguardian.com/technology/gamesblog/2010/nov/19/ assassin-s-creeed-brotherhood-history>. Acesso em: 20 jun. 2013.

TILL, K. Memory Studies. History Workshop Journal, [s.1.], v. 62, n. 1, p. 325-341, Jan. 2006. Disponível em: <http://www.mecodem.eu/wp-content/uploads/2015/05/Bosch2016_Memory-Studies.pdf >. Acesso em: 26 abr. 2016.

VIANA-TELLES, H. Um tecido encharcado de tensões: as formas elementares da memória do Sinditêxil - Bahia. 2009. Tese [Doutorado em Ciências Sociais] - Universidade Federal da Bahia, Salvador, 2009.

; ALVES, L. R. G. Ensino de história e videogame: problematizando a avaliação de jogos baseados em representações do passado. In: ALVES, Lynn; COUTINHO, Isa (Orgs). Jogos Digitais e aprendizagem: fundamentos para uma prática baseada em evidências. São Paulo: Papirus, 2016a, p.125-146.

; ALVES, L. Ficção e narrativa: o lugar dos videogames no ensino de História. TECCOGS: Revista Digital de Tecnologias Cognitivas, [s.1.], v. 1, p. 115-130,2016b. Disponível em: <http://www4.pucsp.br/pos/tidd/teccogs/artigos/2015/edicao_11/ teccogs11_artigo04.pdf>. Acesso em: 26 abr. 2016.

THOMPSON, J. B. Los media y la modernidad: una teoría de los medios de comunicación. Barcelona: Paidós, 1988. 